\title{
UPTAKE OF P32-LABELLED CYCLOPHOSPHAMIDE FROM ARTHRITIC KNEE JOINTS
}

\author{
BY \\ M. I. D. CAWLEY, JOAN M. McAllisteR, A. K. THOULD, \\ AND H. WYKEHAM BALME \\ From St. Bartholomew's Hospital, London, E.C.1
}

The action of cytotoxic drugs such as alkylating agents and antimetabolites on active cell division and on the immune response has led to attempts to measure their efficacy as anti-inflammatory and antiproliferative agents in rheumatoid disease. In the chronic joint lesions of this condition there is proliferation of the synovial membrane with dense infiltration with lymphoid and mononuclear cells. These agents have been used in an attempt to induce a "medical synovectomy" to prevent the progressive erosion of articular cartilage and subsequent destruction of joint architecture, as a possible alternative to surgical synovectomy. The theoretical justification for the use of such drugs rests in both their known action in suppressing cell division and their action in suppressing the immune response, since in rheumatoid disease there are $(a)$ active cell proliferation in the local lesions, $(b)$ an abnormal antibody-like material, the rheumatoid factor, albeit of unknown relevance to the pathogenesis of the disease, and (c) local histological features suggestive of a delayed hypersensitivity type of immune response.

Previous workers using these drugs have obtained varying results, both by systemic and intra-articular administration. The drugs used include nitrogen mustard (e.g. Jiménez Díaz, 1951; Scherbel, Schuchter, and Weyman, 1957); and Thiotepa (e.g. Wenley and Glick, 1964; Pace, Kantor, and McEwen, 1964; Currey, 1965; Zuckner, Uddin, Ramsey, Gantner, Ahern, and Dorner, 1966). In addition 6-Mercaptopurine has been used systematically in systemic lupus erythematosus and in adjuvant arthritis in rats, and methotrexate has been used in psoriasis. The earlier work on this subject has been reviewed by Hitchings and Elion (1963).

*Present appointment: Senior Medical Registrar, Bristol Royal Hospital.

tPresent appointment: Consultant Physician, Royal Cornwall Hospital, Truro.
In the present investigation the authors used cyclo-phosphamide, a nitrogen mustard derivative, $\stackrel{\circ}{N}$ and a drug with the use of which they were more $\triangle$ familiar.

Whilst in many of the previous investigations on the efficacy of these drugs it has been the custom to $Z$

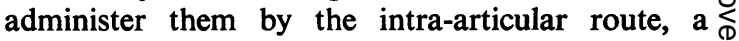
procedure not devoid of hazards, there is little $\frac{}{3}$ information available to indicate whether there is $\underset{\square}{ }$ any advantage in giving the material by this route $\overrightarrow{\mathscr{Q}}$ instead of, for example, intravenously. The autho 8 therefore set out to assess the rate of uptake of. cyclophosphamide from knee joints and its subse quent distribution in the body, on the assumption that a rapid uptake from the joint and redistribution of the material would greatly limit the therapeutic advantages of intra-articular injection. In addition $\varnothing$ an attempt was made to assess whether the simul- $\overrightarrow{\vec{B}}$ taneous injection of hydrocortisone affected the rate $\frac{3}{3}$ of uptake, since this material can be given to reduce $\supset$ the local irritant effect of cytotoxic agents.

\section{Methods}

Seven female and two male patients with definite $\frac{0}{3}$ rheumatoid arthritis according to the criteria of the American Rheumatism Association (1959) or other chronic $\frac{O}{\beta}$ arthritis of proliferative type took part in this study; there was unequivocal clinical synovial thickening in 음 all their knee joints of several years standing, with $D$ effusions. One female (1A and B) was investigated on two different occasions.

A supply of cyclophosphamide labelled with phos- N phorus -32 and sterilized by gamma radiation was kindly $N$ supplied by the Radiochemical Centre, Amersham. This $N$ was provided, mixed with sodium chloride, in dry form; $\omega$ the weight of each constituent was known. The first $\bar{\sigma}$ batch was dispensed, under sterile conditions, into equal 0 aliquots each containing $14 \mathrm{mg}$. cyclophosphamide, and an activity of $40 \mu \mathrm{c}$ of phosphorus ${ }^{-32}$. The specific $\stackrel{?}{?}$ activity of the second batch was higher, and therefore, in 0 order to keep the radioactive dose down to $40 \mu \mathrm{c}$, it 
was split up into aliquots each containing only $9 \mathrm{mg}$. cyclophosphamide. Immediately before injection each aliquot was made up into a 5-ml. solution, using sterile distilled water.

The injection was made, with one exception, into the knee joint, to the medial or lateral side of the patella. The one exception was a control case (Patient 9), in which the cyclophosphamide was injected intravenously. In one patient (1A and $B$ ) the right and left knee joints were both injected, each on a separate occasion. In four of the eleven joints injected $(3,4,5,6)$ hydrocortisone acetate $50 \mathrm{mg}$. was mixed with the injected material.

For the first three investigations with the first batch of cyclophosphamide, two scintillation counters were positioned, one either side of the knee. Their outputs were continuously recorded for periods of time varying from $30 \mathrm{~min}$. to $1 \mathrm{hr}$ after injection. Recordings were made singly and in parallel, in order to check whether the geometry was satisfactory with a single counter. Blood samples were taken at $20 \mathrm{~min} ., 1 \mathrm{hr}$, and $4 \mathrm{hrs}$. Urine was collected for $48 \mathrm{hrs}$, in two $24-\mathrm{hr}$ lots.

With the second batch of cyclophosphamide, six joints were injected (four with hydrocortisone). In these a single counter was used over the knee, one counter over the liver, and a third over the thigh. The outputs from the three counters were continuously recorded for 30 min. to $1 \mathrm{hr}$. Spot measurements were subsequently made over the liver in two patients at intervals up to 4 days. In four patients blood samples were taken, and were collected up to $4 \mathrm{hrs}$ only, but in two patients sampling was continued for 4 days. Also with the second batch, one intravenous injection was given; measurements were made as for the two patients above, who were followed for 4 days (except measurements over the knee).

\section{Results}

(1) The rates of clearance of $32 \mathrm{P}$ from the knee joint are expressed as $T_{\frac{1}{2}}$ (i.e. time to reach half the initial value) in the Table.

The $T_{\frac{1}{2}}$ values for patients 5 and 6 are appreciably shorter than those for the other patients. These two tests were carried out at a later date, 29 days after the receipt of Batch 2. They are, therefore, subject to suspicion; it is possible that the cyclophosphamide may have broken down, so that the 32P label does not represent the clearance of the cyclophosphamide. In all the other tests the material was used not later than 10 days after receipt. The results on patients 5 and 6 have therefore been discarded.

This leaves five injections given under similar conditions without hydrocortisone (Patients 1A, 7 , and 8 with the first batch of cyclophosphamide, and 2 and 3 with the second batch). The $T_{\frac{1}{2}}$ values without hydrocortisone were $32,45,36,50$, and 78 min. (mean 48).

Two injections given under similar conditions with hydrocortisone (Patients 3 and 4) gave $\mathbf{T}_{\mathbf{t}}$ values of 54 and $105 \mathrm{~min}$. respectively. It is interesting to note that the relatively long clearance time of $105 \mathrm{~min}$. occurred in the only patient (4) in whom a firm diagnosis was not possible, and who was latex-negative.

TABLE

RATES OF CLEARANCE OF $\because P$ FROM THE KNEE JOINT

\begin{tabular}{|c|c|c|c|c|c|c|c|}
\hline $\begin{array}{l}\text { Patient } \\
\text { No. }\end{array}$ & Sex & Clinical Data & $\begin{array}{l}\text { Injection } \\
\text { Site }\end{array}$ & $\begin{array}{l}\text { Hydro- } \\
\text { cortisone }\end{array}$ & $\begin{array}{c}\text { Wt } \\
\text { Cyclophos- } \\
\text { phamide } \\
\text { (mg.) }\end{array}$ & $\begin{array}{l}\text { Dose } \\
(\mu c)\end{array}$ & $\underset{\text { (min.) }}{T 1}$ \\
\hline $1 \mathrm{~A}$ & \multirow[t]{2}{*}{$\mathbf{F}$} & \multirow{2}{*}{$\begin{array}{l}\text { Latex + ve } \\
\text { Chronic RA } \\
\text { Steroids }\end{array}$} & R knee & - & 14 & 33 & 32 \\
\hline 1B & & & L knee & - & 9 & $37 \cdot 5$ & 50 \\
\hline 2 & $\mathbf{F}$ & $\begin{array}{l}\text { Latex + ve } \\
\text { RA } \\
\text { Gold therapy }\end{array}$ & L knee & - & 9 & $32 \cdot 5$ & 78 \\
\hline 3 & $\mathbf{M}$ & $\mathbf{R A}^{*}$ & L knee & + & 9 & 25 & 54 \\
\hline 4 & $\mathbf{F}$ & $\begin{array}{l}\text { Latex - ve } \\
\text { "Chronic arthropathy" }\end{array}$ & R knee & + & 9 & 30 & 105 \\
\hline 5 & $\mathbf{F}$ & $\mathbf{R A}^{*}$ & L knee & + & 9 & 10 & $12 \cdot 5$ \\
\hline 6 & $\mathbf{M}$ & $\begin{array}{l}\text { Latex + ve } \\
\text { RA }\end{array}$ & L knee & + & 9 & 10 & 10 \\
\hline 7 & $\mathbf{F}$ & $\begin{array}{l}\text { Latex + ve } \\
\text { RA }\end{array}$ & R knee & - & 14 & $36 \cdot 1$ & 45 \\
\hline 8 & $\mathbf{F}$ & $\begin{array}{l}\text { Latex +ve } \\
\text { RA }\end{array}$ & R knee & - & 14 & $22 \cdot 5$ & 36 \\
\hline 9 & $\mathbf{F}$ & $\begin{array}{l}\text { Latex - ve } \\
\text { RA }\end{array}$ & $\begin{array}{l}\mathbf{L} \text { arm } \\
\text { control Intravenous }\end{array}$ & - & $3 \cdot 6$ & 23 & 40 \\
\hline
\end{tabular}


(2) The variation of the blood activity with time, after injection into the joint (1B and 2), and also after intravenous injection (9) is shown in Fig. 1. The curves show that in the former case it reaches a maximum value of about $25 \times 10^{-4}$ per cent. $/ \mathrm{ml}$. (range 17-35) at $4 \mathrm{hrs}$, and has fallen to about $15 \times 10^{-4}$ per cent. $/ \mathrm{ml}$. (range $11-16$ ) at $24 \mathrm{hrs}$ and to about $3 \times 10^{-4}$ per cent. $/ \mathrm{ml}$. at 4 days.

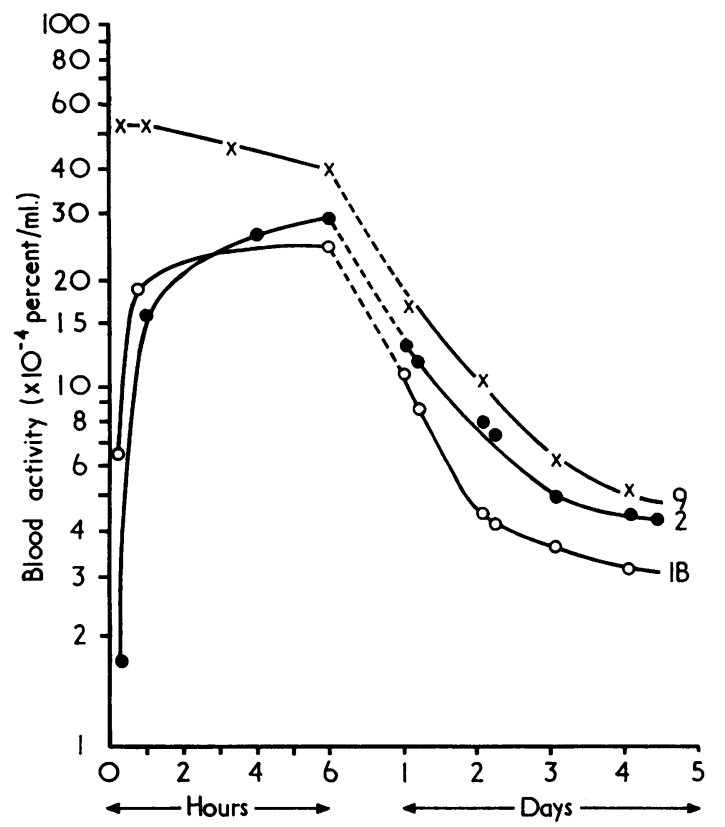

Fig. 1.-Variation of blood radioactivity with time in three patients $(1 \mathrm{~B}, 2,9)$.

The blood curve after intravenous injection is almost identical with the above from $4 \mathrm{hrs}$ onwards, i.e. after the intra-articular injection curve has reached its maximum. At $8 \mathrm{~min}$. the activity was $52 \times 10^{-4}$ per cent./ml. Assuming that at that time all the activity was uniformly distributed in the vascular system, and taking the blood volume at 3.5 1., the total accounted for is 18 per cent. of the dose. Assuming that all the activity was uniformly distributed throughout the extracellular space, of volume $9 \mathrm{l}$., the total activity accounted for is 47 per cent. of the dose.

Most unexpectedly the activity of the blood sample taken at $1 \mathrm{hr}$ was $52 \times 10^{-4}$ per cent. $/ \mathrm{ml}$., the same as that of the sample taken at $8 \mathrm{~min}$.

(3) The counting rates over the liver were very low and therefore subject to large statistical varia- tions. However, in general, after intra-articular injection they followed, fairly closely, the bloodactivity, and there was no evidence of significant localization in the liver. The liver counting rates after intravenous injection showed a downward trend from 2 to $20 \mathrm{~min}$. after injection, while the blood activity was still rising.

(4) The activity appears in the urine at 3 to 6 hrs, and is nearly all excreted by the second or third day.

(5) The distribution of the dose between knees, liver, extracellular fluid (ECF), and urine for two intra-articular injections ( 3 and 4 ), and between liver, ECF, and urine for the intravenous injection (9), is shown in Fig. 2. It has been assumed that the material distributes uniformly throughout the ECF and that the total in the ECF is the blood concentration multiplied by the ECF volume, which has been taken as 22.5 per cent. of body weight.

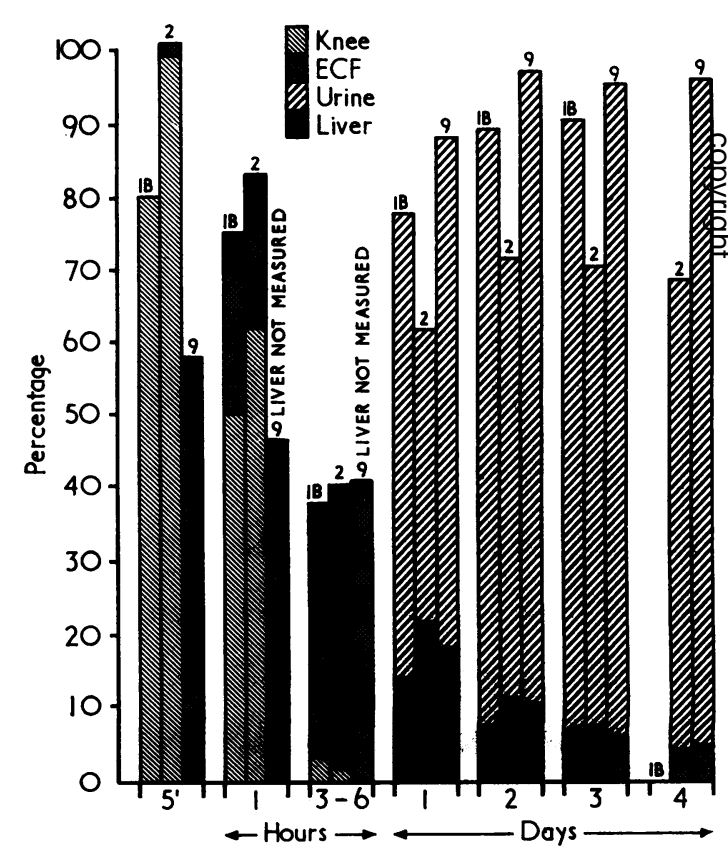

Fig. 2.-Variation of distribution of radioactivity with time in various o tissues in three patients $(1 \mathrm{~B}, 2,9)$.

\section{Discussion}

Cyclophosphamide is a cytotoxic agent developed by Arnold and Bourseaux (1958) and is an alkylating agent of the nitrogen mustard group. It has been 
thought to be activated in the liver or blood (Calabresi and Welch, 1965). The mechanism of the therapeutic action of this compound has not been fully elucidated, although Brock and Hohorst (1967) have produced evidence to show that it is metabolized to a "primary alkylating metabolite", mainly by the liver microsomes, at least in the rat. This metabolite is a weak anion which contains the phosporus moiety, and we have therefore assumed that the amount of $\mathbf{P 3 2}$ parallels the amount of active therapeutic agent. Like other nitrogen mustards (Calabresi and Welch, 1965), it appears to interfere with normal mitoses and cell division in proliferating tissues by alkylation of nucleophilic substances and other biologically important moieties. These compounds have also been shown to suppress antibody production, and lymphocytes are especially sensitive to their action. Although there was only one intravenous injection and measurements over the livers were of limited accuracy, there was a suggestion of some liver uptake of cyclophosphamide when it was injected intravenously. The findings of Brock and Hohorst (1967) have been published since our studies were performed, and these workers do not comment on which liver cells are involved in activation. If the reticuloendothelial cells are involved, it is possible that other sites of activation exist in man, and in particular that such activation might occur in rheumatoid synovium. It would be of interest to have direct experimental evidence of the effect of rheumatoid synovial membrane on cyclophosphamide. This obviously has a very important bearing on the route of administration. If activation does occur in the synovium, there is a strong case for intra-articular injection,* but if not there would seem to be no therapeutic advantages over intravenous or oral administration since the material would have to pass through the liver to be activated.

\footnotetext{
*If the therapeutic effect is considered to be a direct action of cyclophosphamide on the inflammatory reaction in the synovium, it is obviously dependent on the product of the concentration of material in the joint and the duration of its stay in the joint.

i.e. therapeutic effect $\propto$ concentration $\times$ clearance halftime.

FOR EXAMPLE

For intra-articular injection

Therapeutic effect $\propto 0 \cdot 1 \times 50^{\prime}$ (concentration $\propto 0 \cdot 1$, assuming the $\propto 5.0 \quad$ whole dose is injected into a volume of $10 \mathrm{ml}$. $T \frac{1}{t}=50 \mathrm{~min}$.)
}

The results of the present study show that if $\mathbf{P}^{32}$ labelled cyclophosphamide is injected into the joint space, it is cleared with a half-life of about $50 \mathrm{~min}$.

The blood level of cyclophosphamide after intraarticular injection, as shown by radioactivity measurements on venous blood samples, appears to rise to a maximum at between 3 and $6 \mathrm{hrs}$. The concentration in the blood is such that, in order to account for the whole of the injected radioactivity, it is necessary to assume a distribution space larger than the blood volume. This is considered most likely to be represented by the total extracellular compartment, in which the drug is probably freely distributed. If this assumption is made, there are some discrepancies, as shown in Fig. 2. With the intravenous injection, only about 58 per cent. of the dose is accounted for at $8 \mathrm{~min}$., and only 50 per cent. at $1 \mathrm{hr}$ after injection. With the intra-articular injection, about 80 per cent. is accounted for at $1 \mathrm{hr}$. At $4 \mathrm{hrs}$ only 40 per cent. is accounted for in either case, but presumably some of the activity has by that time been excreted (this could not be checked as 24-hr collections were made). The main discrepancy seems to be in the intravenous injection. The blood activity is approximately the same at $1 \mathrm{hr}$ as it is at $8 \mathrm{~min}$. The measurements over the liver suggested a rise during the first $2 \mathrm{~min}$. followed by a fall over the next $20 \mathrm{~min}$. The initial rise could be due to circulating blood activity, but the fall is difficult to account for since the blood activity is not falling. It is conceivable that some of the material was taken up by the hepatic reticuloendothelial cells at $2 \mathrm{~min}$. and subsequently released into the blood, so that between the blood samples at $8 \mathrm{~min}$. and $1 \mathrm{hr}$ there was a rise in the blood activity (corresponding to the decrease in the liver) followed by a fall as the material was cleared from the blood and excreted in the urine. After intra-articular injection the liver activity seemed to follow the blood

$$
\begin{aligned}
& \begin{array}{l}
\text { For intravenous injection } \\
\text { Therapeutic effect } \propto 10^{-4} \text { per cent. } \times 15 \times 60 \\
\propto 0.09
\end{array} \begin{array}{l}
\text { (concentration } \propto 10^{-4}, \text { assuming the } \\
\text { whole dose is distributed in a volume } \\
\text { of } 101 . \mathrm{T} / \mathrm{t}=15 \mathrm{hrs})
\end{array} \\
& \frac{\text { Therapeutic effect for } \mathrm{I} / \mathrm{A} \text { injection }}{\text { Therapeutic effect for } \mathrm{I} / \mathrm{V} \text { injection }}=\frac{5.0}{0.09} \simeq 50
\end{aligned}
$$

This is very approximate, but after 6 hrs the blood curves for intra-articular and intravenous injections are almost identical, so the approximation tends to minimize the ratio. We can therefore conclude that with local activation intra-articular injection would be at least fifty times as potent as intravenous injection. 
activity fairly closely. It was anticipated that cyclophosphamide might be selectively taken up and concentrated in the reticuloendothelial system; our measurements after intra-articular injection showed little evidence for this, but the hypothesis could account for the results of measurements after intravenous injection. In view of the low counting rates over the liver, which gave rise to large statistical variations, and the obvious difficulties of absolute measurements, it is not possible to draw any definite conclusions about this. Rapid serial blood samples after an intravenous injection might help to elucidate our results.

The therapeutic efficacy of intra-articular cyclophosphamide in patients with rheumatoid synovitis remains to be established. In a small pilot survey by the authors in which the effect of several weekly intra-articular injections of cyclophosphamide plus hydrocortisone was compared with that of hydrocortisone alone, no significant clinical difference was found between the two groups after 1 to 2 years' interval. Hydrocortisone was given by us with cyclophosphamide in these cases since it was observed that it prevented the acute inflammatory reaction that sometimes occurred with the latter drug in the doses used for therapy $(200 \mathrm{mg}$.).

\section{Summary}

The results of a study of the uptake of $\mathrm{P}^{32}$. labelled cyclophosphamide from arthritic human knee joints are presented. These indicate that the material is cleared from the joint under standardized conditions to give a clearance half-time of approximately $50 \mathrm{~min}$. No evidence was obtained that the simultaneous administration of hydrocortisone ( 50 mg.) affected the clearance time. On theoretical grounds, the relative benefits of intra-articular as compared with other routes of administration would depend on whether or not activation of cyclophosphamide takes place in the synovial membrane.

Our gratitude is due to the patients at St. Bartholomew's and Whipps Cross Hospitals who kindly cooperated in this study; to the Radiochemical Centre at Amersham, Bucks., for the supply of $\mathrm{P}^{32}$-labelled cyclophosphamide; to the Staff of the Radioisotope Department, particularly to Mr. A. E. Houlder, at St. Bartholomew's Hospital, for the extensive measurements and calculation of radioactivity; and to Dr. P. A. Bacon for clinical assistance.

\section{REFERENCES}

American Rheumatism Association (1959). Ann. rheum. Dis., 18, 49 (Diagnostic criteria for rheumatoid arthritis: 1958 revision).

Brock, N., and Hohorst, H. J. (1967). Cancer, 20, 900 (Metabolism of cyclophosphamide).

Calabresi, P., and Welch, A. D. (1965). " "The Pharmacological Basis of Therapeutics", 3rd ed., ed. L. S. Goodman and A. Gilman, chap. 62, pp. 1345-1357. Macmillan, New York.

Currey, H. L. F. (1965). Ann. rheum. Dis., 24, 382 (Intra-articular thiotepa in rheumatoid arthritis).

Hitchings, G. H., and Elion, G. B. (1963). Pharm. Rev., 15, 365 (Chemical suppression of the immune response).

Jiménez Díaz, C. (1951). Ann. rheum. Dis., 10, 144 (Treatment of dysreaction diseases with nitrogen mustards).

Pace, N., Kantor, T., and McEwen, C. (1964). Arthr. and Rheum., 7, 337 (Abstract: evaluation of intra-articularly injected alkylating agents in arthritis).

Scherbel, A. L., Schuchter, S. L., and Weyman, S. J. (1957). Cleveland clin. Quart., 24, 78 (Intraarticular administration of nitrogen mustard alone and combined with a corticosteroid for rheumatoid arthritis. Experimental and clinical studies).

Wenley, W. G., and Glick, E. N. (1964). Ann. phys. Med., 7, 287 (Medical synovectomy with thiotepa).

Zuckner, J., Uddin, J., Ramsey, R. H., Gantner, G. E. (Jr.), Ahern, A. M., and Dorner, R. W. (1966). Ann. rheum. Dis., 25, 178 (Evaluation of intra-articular thiotepa in rheumatoid arthritis). 
L'absorption du cyclophosphamide contenant $\mathbf{P}^{32}$ par l'articulation arthritique du genou

\section{RÉSUMÉ}

Les résultats d'une étude de l'absorption du cyclophosphamide $\mathrm{P}^{32}$ par l'articulation arthritique du genou de l'homme sont présentés. Ils indiquent que la moitié de ce produit est éliminée de l'articulation sous des conditions standards dans à peu près 50 minutes. Aucune preuve n'a été obtenue que l'administration simultanée de l'hydrocortisone $(50 \mathrm{mg}$.) affectait la période d'élimination. Pour des raisons théoriques les avantages relatifs de l'administration intra-articulaire à comparer aux autres voies d'administration dépendraient de l'activation ou non du cyclophosphamide dans la membrane synoviale.
Absorción de ciclofosfamida identificada con $\mathbf{P}^{32}$ en articulaciones de rodillas artríticas

\section{Sumario}

Se exponen los resultados de un estudio sobre la absorción de ciclofosfamida identificada con $\mathbf{P}^{32}$, en articulaciones de rodillas artríticas humanas. Estos indican que el material desaparece de la articulación en condiciones estandardizadas, para dar un tiempo medio de eliminación de aproximadamente $50 \mathrm{~min}$. No hubo pruebas de que la administración simultánea de hidrocortisona $(50 \mathrm{mg}$.) afectase el tiempo de eliminación. Teóricamente, los beneficios relativos del método intraarticular, comparado con otras vías de administración, dependerán de que la activación de la ciclofosfamida se lleve o no a cabo en la membrana sinovial. 